\title{
Experimental study of the influence of glass cover cooling using evaporative cooling process on the thermal performance of single basin solar still
}

\author{
M. S. Manjunath ${ }^{1,2}$, S. V. Kota Reddy ${ }^{1 *}$, V. Shrikanth ${ }^{2}$, Gagan Shetty ${ }^{1}$, S.A. Rakesh ${ }^{1}$, Jinu Mary John ${ }^{1}$, Suhaib Ahmed ${ }^{1}$ and Afnan \\ Aftab1 \\ ${ }^{1}$ School of Engineering and IT, Manipal Academy of Higher Education, Dubai Campus, \\ DIAC-G-008, International Academic City, P.O. Box 345050, Dubai, UAE. Phone: +971 561148592 \\ ${ }^{2}$ Department of Mechanical and Manufacturing Engineering, Manipal Institute of Technology, Manipal Academy of Higher Education, Manipal, \\ 576104, Karnataka, India.
}

\begin{abstract}
Acute shortage of drinking water has been on the rise owing to increasing population as well as shortage of drinkable water. Generation of potable water using passive solar stills is among the simplest and easier devices which make use of solar heat energy. However, the output of solar still is generally low owing to greater heat loss and needs improvement. In this paper, an experimental analysis is carried out to determine the performance of passive solar still with glass cover cooling using cold water generated using passive evaporative cooling process. The cold water required for cooling the glass cover is obtained using evaporative cooling process in the water tank which is wound with wet cotton cloth wick. The cold water thus obtained is sprayed onto the top surface of glass cover. The experiment is carried out in the outdoor conditions of Dubai from 10:00h to 14:00h and the temperature recordings of basin plate, glass cover, basin water, ambient air and cooling water are noted for every 30 minutes. The results reveal that the average increase in condensation heat transfer coefficient is found to be about $20.8 \%$ higher in the presence of glass cover cooling and the distillate output is found to increase by about 3.32 times. The average still efficiency is found to be relatively higher in the presence of cooling which is about $7.3 \%$ higher in the presence of cooling. The cold water temperature generated through evaporative cooling process is about $20.4 \%$ lower as compared to ambient temperature. Thus, the cooling of glass cover using cold water obtained through evaporative cooling process is found to be effective in enhancing the thermal performance of single basin solar still system.
\end{abstract}

ARTICLE HISTORY

Revised: $13^{\text {th }}$ Sept 2019

Accepted: $25^{\text {th }}$ Sept 2019

\section{KEYWORDS}

Solar Still;

desalination;

single basin;

evaporative cooling,

glass cover cooling.

\section{INTRODUCTION}

Population has been on the rise every year and the resources have continuously fallen short to meet the ever increasing demand. Drinking water is among the essential resources and has been found to be in acute shortage in most parts of the world due to various factors. In particular, the desert locations where the rainfall is a rarity, the drinking water is found to be very much in shortage. Unfortunately, the ground water is not available everywhere and the existing ones are drying up at faster rate. However, most part of the earth is covered by ocean water which, although is not drinkable in its original content, could be converted to be fit for drinking through the process of evaporation and distillation.

The simplest technique to convert saline water to potable water is to make use of solar stills which use solar heat energy to evaporate the saline water thereby generate distilled drinkable water. These devices have low operating cost and capital investment. The biggest limitation is in the distillation capacity of solar stills which are generally lower. This requires special enhancement techniques to be used to increase the distillation output viz increasing the evaporation rate, condensation rate and use of focused solar heat as reported in the literature. Distillation is the most efficient, cost effective and easy method to get clean water by recycling brackish water, sewage water or any other form of contaminated water. The main reason why distillation process is considered as cost efficient and cheap is that the solar energy is abundantly available free of cost which can be used for the process. While many people still try to boil water to try to distill it adding additional unwanted cost, solar still can distillate water without any additional cost.

Several studies have been reported in the past on the improvement of thermal performance of solar still through different techniques such as improving the solar heat absorption using external and internal reflectors, improving distillate output through humidification and dehumidification process and improving the evaporation and condensation rate. The challenge has always been with respect to the limitations associated with cost and conversion efficiency [1]. Sellami et al. [2] made use of layers of sponge on the absorber plate and were blackened in color. They evaluated the effect of sponge thickness on the distillate output. The sponge layers were intended to act as heat storage medium. They found that the sponge thickness of $0.5 \mathrm{~cm}$ produced about 58\% higher water output as compared to base model. Various techniques [38] have been used for improving still performance such as fins, multi-basin solar stills, use of solar chimneys for desalination, use of nanofluids and use of energy storage system. It is found that that the use of fins could increase the 
surface area thereby increasing the rate of evaporation and condensation which in turn increases the efficiency and productivity of the solar still. Sharshir et al. [9] made use of hybrid solar desalination system where a humidification dehumidification system was combined with the solar still basin evacuated tube solar water heater system. The drained water from the humidification and dehumidification system was reused in the solar still which helped in achieving about $50 \%$ higher distillate output as well as reduce the cost of distilled water.

Abdallah et al. [10] made use of internal as well as external reflectors in the still basin to improve the incident solar heat on the basin plate to augment the evaporation rate. Use of reflectors is a relatively low-cost option and was found to increase the output gain as well as efficiency by about $30 \%$. The performance of double and single slope stills has also been compared with the use of reflectors. The results show that the use of internal reflectors in a single slope still provides $20 \%$ higher output as compared to double slope still. Use of external reflectors alone has been shown to augment the productivity by about $9 \%$ a year [11]. El-Samadony et al. [12] made use of external reflectors as well as external condenser in a stepped solar still system. The use of external condenser was to condense the water from the air driven through the solar still. The output was found to increase by about $165 \%$ over the conventional still system. Mu et al [13] made use of Fresnel lens to focus the radiations on the still surface to increase the evaporation rate which was found to be very effective, although the use of focusing lens requires sun tracking system which adds to the cost and weight of the system. Yousef and Hassan [14] investigated the performance of a single sloped solar still by comparing the performance of conventional still, a still with a phase change medium at the basin plate, with hollow pin fins in the PCM and the model with only steel and wool fibres attached on the plate. Use of steel and wool fibres alone was found to increase the productivity by about $25 \%$ as compared to other cases. Abu-Arabia et al. [15] developed a solar still model which is connected to an external still and having sodium thiosulphate pentahydrate as a phase change material which is used to supply thermal energy during the times of low or no sunlight to ensure continuous production of water. The cooling water passing through the glass cover within the still increased the productivity of the fresh water from 0.01 to $0.1 \mathrm{~kg} / \mathrm{s}$. Winston et al. [16] conducted experiments on PV/T active solar still for different depths of water in the water basin. The PV cell power output was used to heat up the water along with the solar heat to enhance evaporation rate. The PV cells were cooled using the water that is supplied to the still thereby improving the PV cell output. The daily productivity was found to be about 6 times higher as compared to conventional system. The rate of condensation of vapor underneath the glass cover can be increased by providing increased heat transfer through the glass cover.

Improving the condensation rate has been shown to improve the distillate output and still efficiency. Condensation rate can be increased through glass cover cooling, increasing the glass cover surface area and using exclusive condensers. Cooling of glass cover [17] has been shown to provide increased condensation rate owing to greater temperature difference between the basin water and glass cover. The cooling of glass cover can be accomplished using ambient water or air and the productivity increases with increasing temperature difference between the glass and basin water. Use of cold water [18] will be even more advantageous where a further higher temperature difference could be created between the glass and basin water and the efficiency was found to increase by about 6\%. Desert cooler system was used by Aneesh and Anil [19] to generate cold water which was dripped down the glass cover. The spent water flowing down the glass cover was recirculated back to the air cooler system. The yearly productivity was found to be about $56.5 \%$ as compared to $21.8 \%$ when cooling was done using water at ambient conditions. Water sprinkler system was used by Tarawneh [20] where ambient temperature water sprinkled onto the top surface of glass cover improved the productivity by about $75 \%$.

Thus, it has been shown in the past that lowering of glass cover temperature of solar still results in improved thermal performance. However, the previous studies made use of water at ambient temperature conditions to cool the glass cover of solar still in view of additional cost involved for cooling the water. There has been very limited emphasis on lowering the glass cover temperature using cold water obtained from passive evaporative cooling process. The cold water could be generated by using passive evaporative cooling process much in the same way as clay pot water cooling process and could be very effective in enhancing the thermal performance. In this paper, an experimental investigation is carried out on a double slope single basin solar still with glass cover cooling achieved using passive evaporative cooling process. The evaporation of water in the cotton wick which is wound around the water storage tank creates cooling effect thereby creating cold water. The performance of the still system with and without cooling is brought out in terms of solar still efficiency and distillate output.

\section{EXPERIMENTAL SET UP}

\section{Geometric Details of the Solar Still}

The solar still consists of a rectangular basin made up of Galvanized Iron (GI) sheet metal and has the dimensions of $400 \mathrm{~mm}$ x $600 \mathrm{~mm}$ x $3 \mathrm{~mm}$. The solar still was fabricated at the workshop of the campus. The solar still is constructed in the form of a rectangular basin as shown in Figure 1 and does not involve inclination with respect to the ground where the latitude and longitude of the location is about $25.2048^{\circ} \mathrm{N}$ and $55.2708^{\circ} \mathrm{E}$. This is because, the inclination makes the water stored in the basin to pile up on one side thereby increasing the depth of water which reduces the transmitted radiation through the water column leading to reduced thermal performance. The GI sheet basin is enveloped by a layer of thermocol which has a low thermal conductivity of $0.033 \mathrm{~W} / \mathrm{mK}$ followed by plywood sheet to reduce the heat loss. The GI sheet is used as the solar radiation receiver and is painted black on its surface to achieve greater absorptivity of solar radiation. Thermocol is used as insulation to prevent heat loss from the GI basin and is economical, easily available and lightweight. The complete constructional details of the solar still used in the analysis are shown in Figure 1. An overview of the experimental set up is shown in Figure 2. The glass cover used has a thickness of $5 \mathrm{~mm}$ and is arranged 
with double slope so as to provide greater condensation surface area which enhances the distillation rate. The water level on the GI absorber plate is maintained as $1 \mathrm{~cm}$ as reported by Rajamanickam and Ragupathy [22] as greater water levels have been shown in the literature to decrease the condensation rate. In the current experiment, the water is poured on the basin to a depth of $1 \mathrm{~cm}$ before the start of the experiment. Once the experiment starts, the water depth will gradually reduce a little bit due to evaporation and the change in depth is not significant due to low evaporation rate within the duration of experiment. The glass cover has cooling water flow arrangement that is pumped from the water container placed on the ground. The cooling water is recirculated to the storage tank for recycling. The water container has a cotton wick wound around it and is wetted with water. The wick creates cooling in the water through evaporative cooling process and the cold water thus obtained is then sprayed onto the glass cover as shown in Figure 3. A small submersible pump is used in the cold water container to force the cold water to the perforated pipe fitted on top of the glass cover as shown in Figure 2.The temperature of cold water was not controlled to maintain any particular value and it varied with the time of the day during the experiment. The sprayer pipe consisted of 38 holes each of about $3 \mathrm{~mm}$ diameter so as to maintain a fine water line output. The number of holes were so chosen to ensure complete coverage of glass cover by the dripping water.

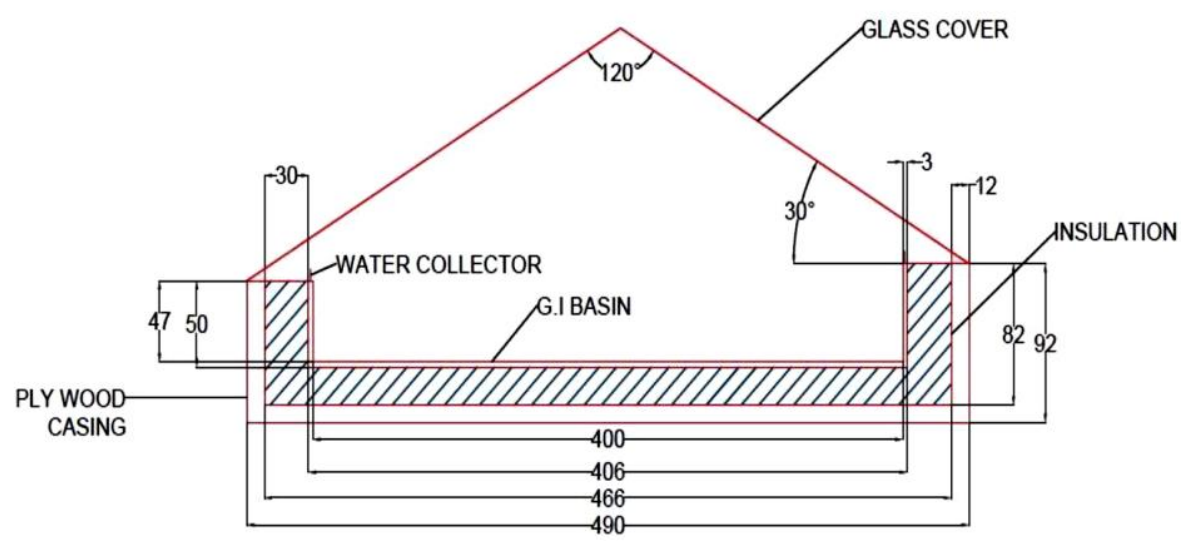

Figure 1. Constructional details of solar still used in the analysis.

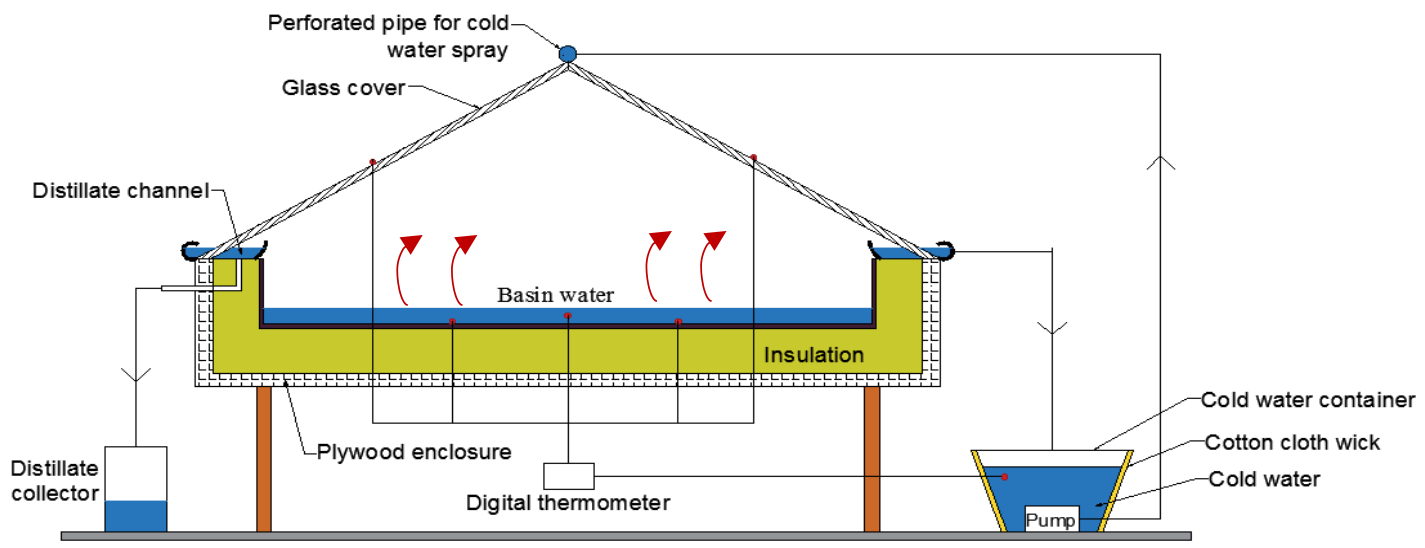

Figure 2. Overall arrangement of solar still with water cooling arrangement on glass cover. 


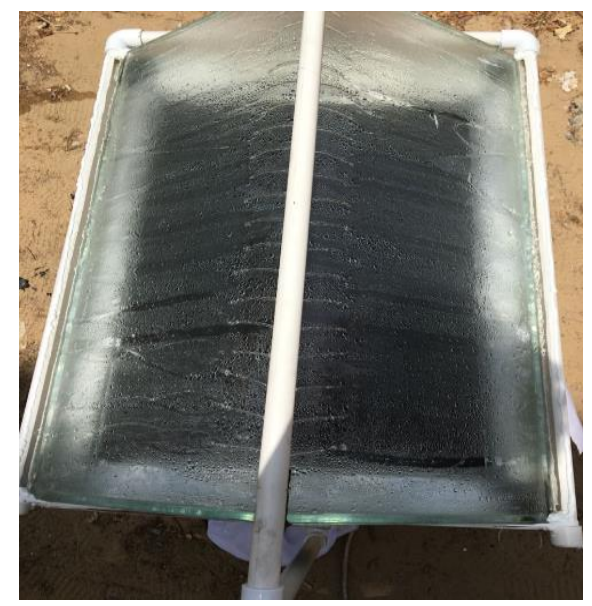

Figure 3. Cooling water spray on glass cover.

\section{Experimental Procedure}

The experimental is conducted in the outdoor conditions of Dubai, UAE in the month of May during and the global solar irradiance for the time period of 10:00h to $14: 00 \mathrm{~h}$ is determined by using the freely available online solar radiation calculator called 'Solar Position and Intensity' (SOLPOS) calculator provided by the National Renewable Energy Laboratory NREL [23]. The global solar irradiance is found to vary between $1100 \mathrm{~W} / \mathrm{m}^{2}$ and $1300 \mathrm{~W} / \mathrm{m}^{2}$ as shown in Figure 4.

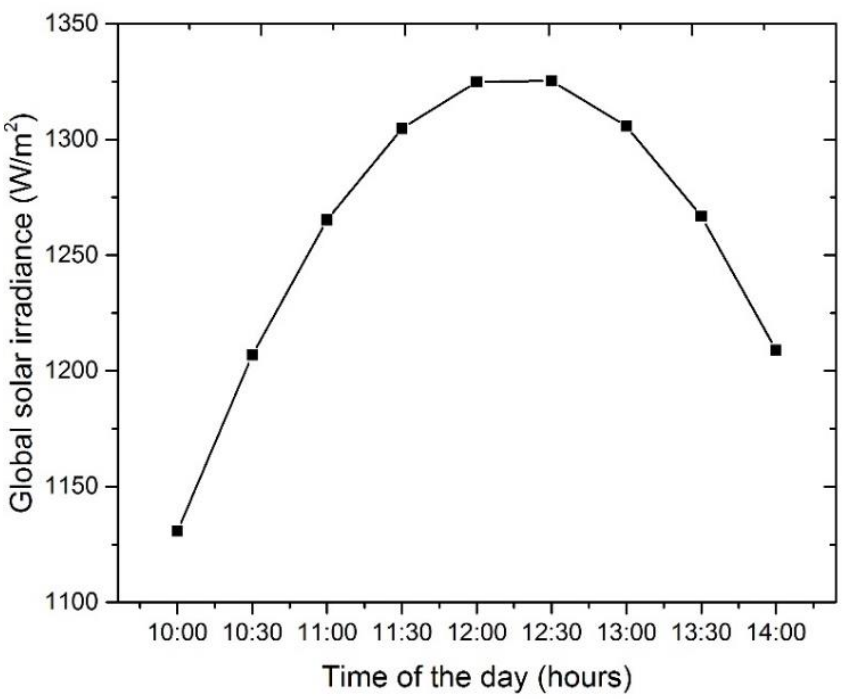

Figure 4. Variation of global solar irradiance for the month of May in Dubai location as per SOLPOS [23].

The water in the basin is filled to a depth of $1 \mathrm{~cm}$ and the glass covers are sealed for air leakage. A digital thermometer with LCD display (Model: BENETECH GM1312) is used to indicate the temperature readings using k-type thermocouples. The thermocouples are attached on the basin plate, in the basin water and on the glass cover to measure the temperatures. A total of seven thermocouples are used in the analysis where two were used on the basin plate and glass cover and one each for basin water, cold water and ambient air. The thermometer has a resolution of $0.1^{\circ} \mathrm{C}$ with an accuracy of $\pm 1.5 \%$. Though a detailed calibration of thermometer was not carried out, the readings of digital thermometer were randomly compared against the mercury thermometer readings and the readings were found to have very close agreement. The experiment is carried out in the outdoor conditions from 10:00h to 14:00h during which the solar radiation was found to be at its peak. The water stored in the container is cooled by evaporative cooling where the cotton cloth wound around the water container is sprayed with water periodically. The water sprayed onto the cotton cloth evaporates into the surrounding air thereby absorbing the heat from within the water creating a cooling effect on the tank and hence the water stored in it. This cold water is then pumped to the pipelined on placed on top of the glass cover where the water is sprayed all over it with the help of perforated pipe. The temperature readings of glass cover, basin water, basin plate and outside air constantly noted every 30 minutes. The condensate was collected using two channels along the longer side of the rectangular basin which allow the water to flow down to water collector placed outside the basin through an outlet pipe. 


\section{PERFORMANCE PARAMETERS OF THE SOLAR STILL}

\section{Solar Still Efficiency}

The solar still efficiency [21] is calculated using,

$$
\eta=\frac{q_{e w}}{I(t)}
$$

where, $I(t)$ is the solar radiation intensity in $\mathrm{W} / \mathrm{m}^{2}, q_{e w}$ is the evaporative heat transfer rate in $\mathrm{W} / \mathrm{m}^{2}$ and $t$ refers to the time of the day.

\section{Evaporative Heat Transfer Rate}

The evaporative heat transfer rate [21] is given by,

$$
q_{e w}=h_{e w} \times\left(T_{w}-T_{g}\right)
$$

where, $T_{w}$ and $T_{g}$ refers to the temperature of basin water and glass cover respectively.

\section{Evaporative Heat Transfer Coefficient}

The evaporative heat transfer coefficient [21] is given by,

$$
h_{e w}=16.273 \times 10^{-3} \times h_{c w} \times\left(\frac{P_{w}-P_{g}}{T_{w}-T_{g}}\right)
$$

where, $P_{w}$ and $P_{g}$ refers to partial vapor pressure corresponding to basin and glass cover temperatures respectively and are given by,

$$
\begin{aligned}
& P_{w}=e^{\left(25.317-\frac{5144}{T_{w}+273}\right)} \\
& P_{g}=e^{\left(25.317-\frac{5144}{T_{g}+273}\right)}
\end{aligned}
$$

\section{Condensation Heat Transfer Coefficient}

The condensation heat transfer coefficient [21] is given by,

$$
h_{c w}=0.884 \times\left[T_{w}-T_{g}+\frac{\left(P_{w}-P_{g}\right)\left(T_{w}-T_{g}\right)}{268.9 \times 10^{3}-P_{w}}\right]^{1 / 3}
$$

\section{RESULTS AND DISCUSSIONS}

The variations in the temperature of still basin plate, basin water, ambient air as well as the glass cover is of interest as it influences the overall thermal performance of the solar still and a comparison is brought out between the solar still with and without glass cover cooling. Figure 5 shows the relative variation of temperature of basin plate, ambient air, basin water and glass cover for the time period of 10:00 h to 14:00 h for the case of solar still without glass cover cooling (Base still). It is seen that the temperatures generally increase with time within the time duration of the experiment.

This is due to the fact that the solar intensity increases during the period of experiment which increases the absorbed solar thermal energy in the basin plate. The increased solar radiation incident on the basin plate increases its temperature which furthers rises the water stored above its surface. The higher temperature of water leads to increased evaporation rate and hence releases greater quantity of vapors into the basin air region which in turn increases the basin air temperature as shown in Figure 5. As a result of this, more vapors are available at the glass cover which gets condensed on it thereby releasing the heat of condensation which raises the glass temperature. In addition, the glass cover is directly exposed to solar radiation and absorbs heat thereby raising its temperature as well. The basin plate is found to have the highest temperature in the solar still as shown in Figure 5. This is due to its higher solar radiation absorptivity of the blackened basin plate surface. The water stored on the plate surface absorbs this heat and is found to have temperatures closer to the plate temperatures. The glass cover is found to exhibit the lowest temperatures among all others as it is exposed to ambient air which absorbs the heat from the hot glass plate by convection heat transfer process. Since, the experiment is carried out in outdoor conditions, the temperatures are bound to vary with time owing to varying wind speeds which affect the glass cover heat loss and hence the condensation rate. 


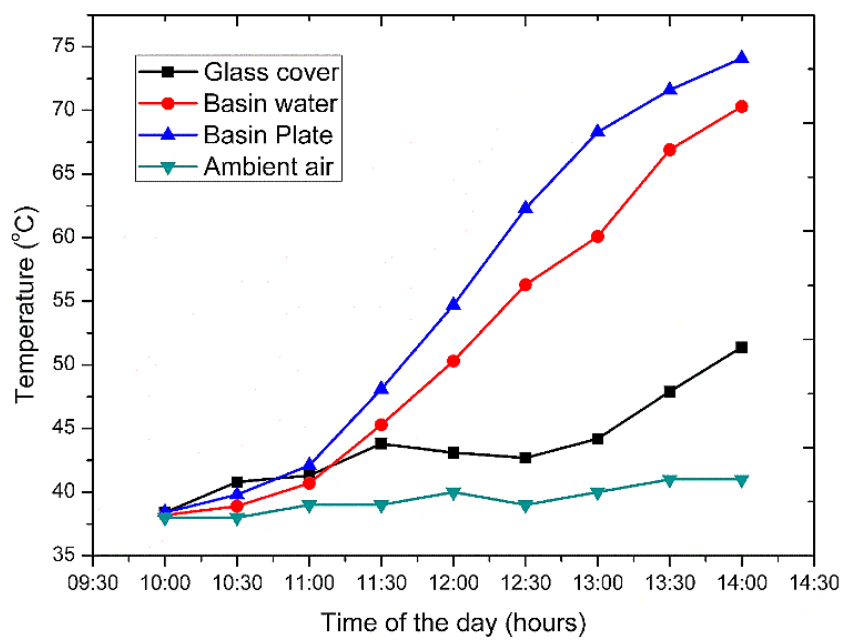

Figure 5. Variation of temperatures of different components of base solar still.

Figure 6 shows the variation of temperature of basin plate, ambient air, basin water and glass cover for the time period of 10:00 $\mathrm{h}$ to 14:00 $\mathrm{h}$ for the solar still with glass cover cooling. It is seen that the temperature variation has similar trend with reference to Figure 5, although the temperature levels are slightly different. The cooling of glass cover has been found to influence the temperature of glass cover basin plate as well as the basin water. The average drop in the temperature of basin plate is found to be about $3.1 \%$ while the average basin water temperatures dropped by about $3.5 \%$ in the presence of glass cover cooling. The basin plate temperature as well as basin water did not change significantly due to the indirect cooling effect caused by the glass cover cooling as well as due to continuous exposure of the basin plate to sun light. Also, owing to the cooling of glass cover, the glass cover temperature is found to be lower than the ambient air as compared to the case of solar still when no cooling was used. The cooling water is seen to have the lowest temperature in the system owing to evaporative cooling.

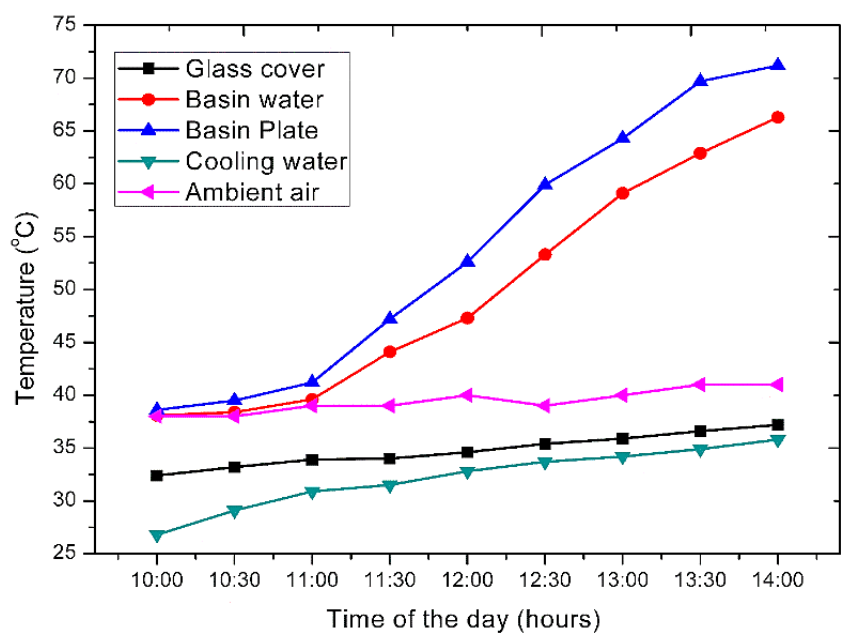

Figure 6. Variation of temperatures of different components of solar still with glass cover cooling.

Figure 7 shows the comparison of temperature of glass cover for the stills with and without cooling system. It is seen that the glass cover temperature in the presence of cooling is considerably lower than that of base still. The maximum temperature difference of glass cover with and without cooling is found to be about $16^{\circ} \mathrm{C}$ as shown in Figure 7 . The average decrease in the glass cover temperature is about $20.4 \%$ in the presence of cooling. The cold water sprayed onto the top of glass cover removes heat of condensation as well as the solar heat absorbed by the glass cover thereby lowering its temperature. This leads to increased condensation rate on the underneath of glass cover. This is indicated by a relatively higher convective heat transfer coefficient for condensation heat transfer as shown in Figure 8. The average increase in condensation heat transfer coefficient is found to be about $20.8 \%$ higher in the presence of glass cover cooling. Consequently, more and more vapors condense as water thereby resulting in a relatively lower vapor pressure corresponding to the reduced glass cover temperature. This in turn leads to increased vapor pressure differential between the vapor pressure corresponding to basin water temperature and vapor pressure corresponding to glass cover temperature as shown in Figure 9. It is clearly seen that the presence of glass cover cooling results in increased vapor pressure differential between the glass cover and basin water. 


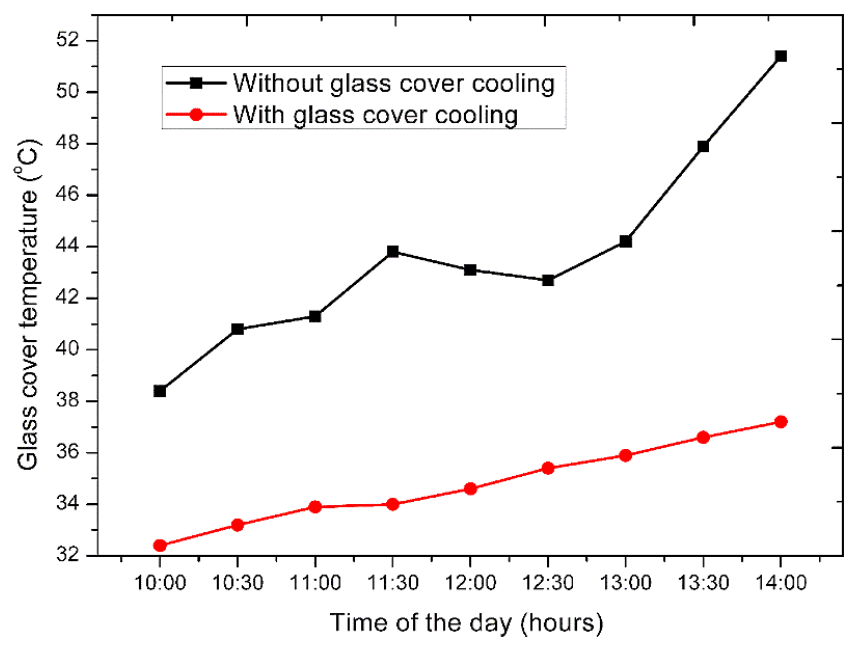

Figure 7. Comparison of glass cover temperature for solar still with and without water cooling.

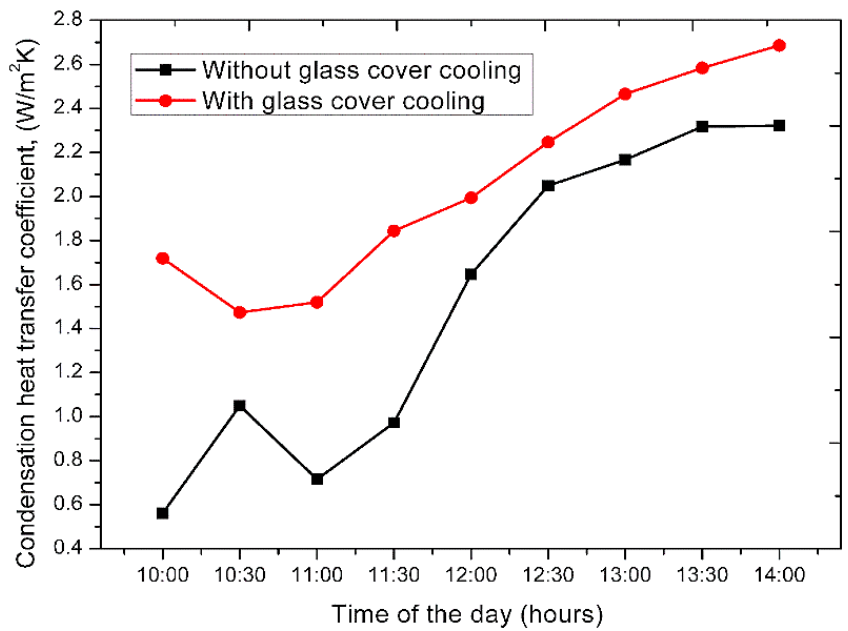

Figure 8. Comparison of condensation heat transfer coefficient for solar still with and without water cooling.

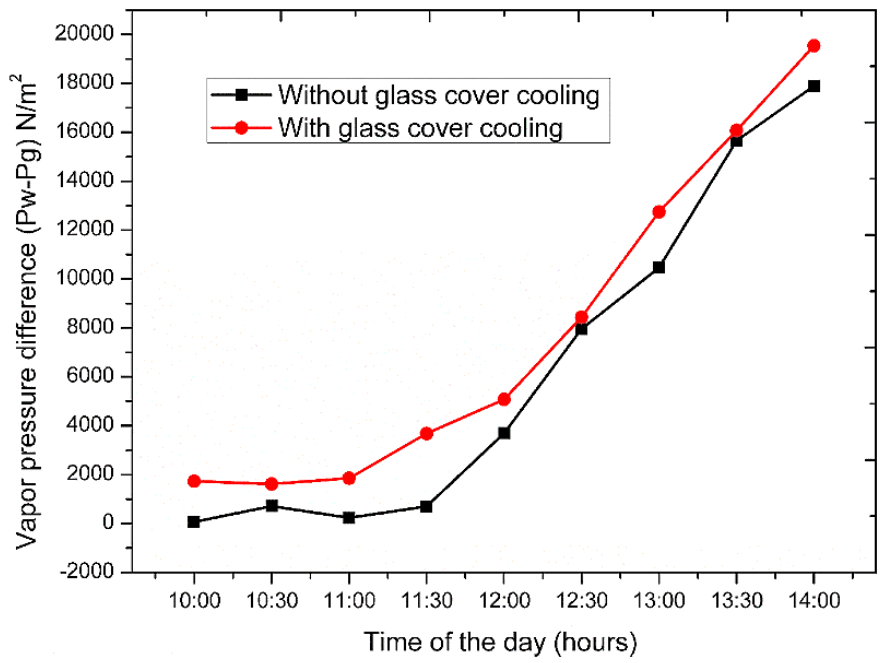

Figure 9. Comparison of vapor pressure differential for solar still with and without water cooling.

Figure 10 shows the comparison of temperature differential between the basin water and glass cover with and without glass cover cooling. It is seen that the temperature differential between the basin water and glass cover is relatively higher by about $6.3^{\circ} \mathrm{C}$ in the presence of glass cover cooling. The water spray on the glass cover provides direct cooling effect thereby reducing its temperature. However, the basin water temperature is indirectly affected by the glass cover cooling. 
The relatively lower temperature of glass cover in turn condenses more vapor thereby creating a relatively reduced vapor pressure on the glass cover side. This leads to increased vapor pressure differential between the basin water and vapor at the glass cover side. This increased vapor pressure differential drives more and more basin water into vapor state so as to achieve pressure equilibrium between the basin water and glass cover side. The basin water evaporates by absorbing latent heat from within the basin water thereby reducing the basin water temperature. Thus, the temperature of both basin water and glass cover are found to decrease in the presence of cooling. However, the glass cover temperature decreases to a greater extent due to direct contact with the cooling water as compared to the basin water and hence the temperature differential between the glass cover and basin water increases in the presence of cooling.

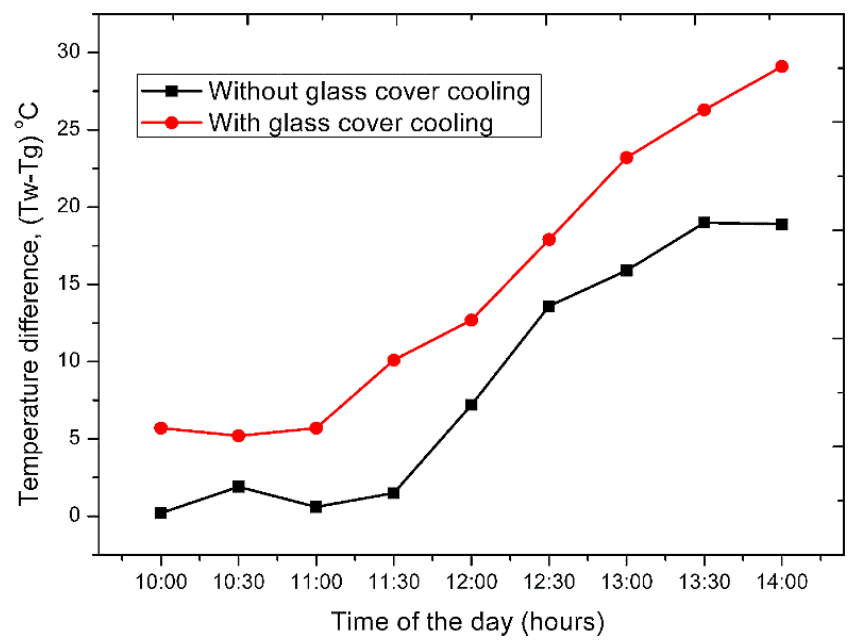

Figure 10. Comparison of temperature differential for solar still with and without water cooling.

Figure 11 shows the comparison of evaporative heat transfer rate from basin water with and without glass cover cooling. It is seen that the glass cover cooling improves the evaporative heat transfer rate from basin water and the average increase is found to be about $80 \mathrm{~W} / \mathrm{m}^{2}$. The glass cover cooling has an indirect effect on the evaporative heat transfer rate where the increased temperature differential leads to increased heat energy exchange between the basin water and glass cover.

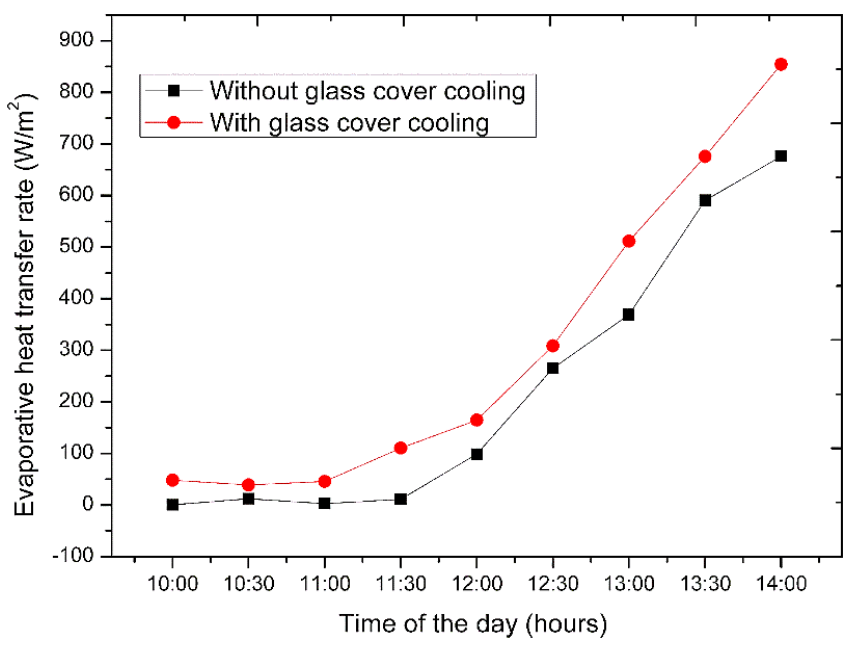

Figure 11. Comparison of evaporative heat transfer rate for solar still with and without water cooling.

Figure 12 shows the comparison of distillate output with and without glass cover cooling. It is seen that the distillate output is about $691 \mathrm{ml}$ in the presence of cooling as compared to $208 \mathrm{ml}$ without cooling which is about 3.32 times higher. The presence of cooling on the glass cover removes the heat from the vapor at a faster rate thereby increasing the condensation rate of vapors leading to a relatively higher distillate output. In the absence of cooling, the glass cover is directly exposed to ambient air and the heat removal rate is dependent on the wind speed and temperature and the glass cover temperature is relatively higher. The hot vapors which come in contact with the relatively higher temperature glass cover encounter a relatively lower temperature differential between them which limits the heat energy exchange. As a result, the condensation rate is also lower thereby producing a relatively lower distillate output. 


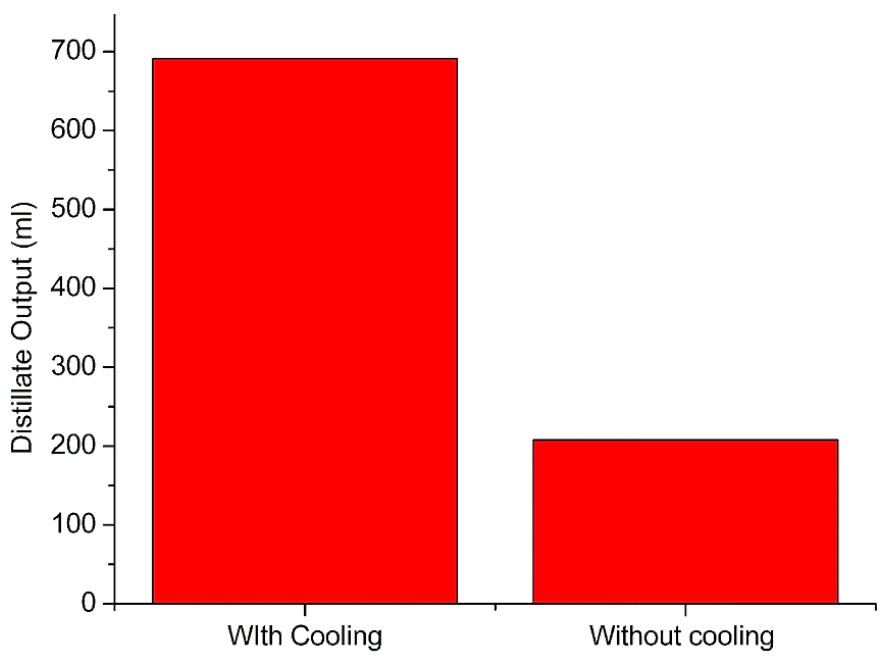

Figure 12. Comparison of distillate output for solar still with and without glass cover cooling.

Figure 13 shows the comparison of solar still efficiency with and without glass cover cooling. It is seen that the average increase in solar still efficiency is about $7.3 \%$ higher in the presence of cooling which indicates that the incident solar radiation energy is utilized better to provide increased distillate output. Increased heat removal from the hot vapors is vital to produce greater distillate output and the presence of glass cover cooling ensures is found to achieve this aspect.

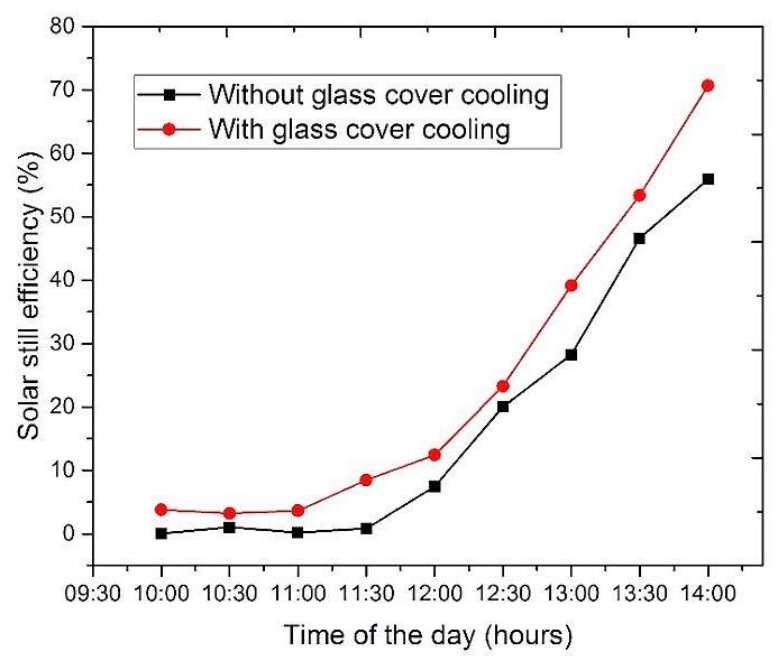

Figure 13. Comparison of solar still efficiency for solar still with and without water cooling.

\section{CONCLUSIONS}

The paper presents an experimental study of solar still with glass cover cooling using passive evaporative cooling process for generating cooling water. The water depth on the basin plate is maintained at $1 \mathrm{~cm}$ and the experiment is carried out under the outdoor conditions of Dubai, UAE for the time period of 10:00 h to 14:00 $\mathrm{h}$. The cooling of glass cover is done on the external surface of glass cover and its impact on solar still efficiency and distillate output is brought out. The following are the major findings of the analysis:

- The glass cover cooling leads to increased temperature difference between the glass and basin water and is found to be about $20.4 \%$ lower than the still without cooling water supply.

- The average increase in condensation heat transfer coefficient is found to be about $20.8 \%$ higher in the presence of glass cover cooling

- The distillate output increased by about 3.32 times as compared to that without cooling.

- The average increase in solar still efficiency is about $7.3 \%$ with the use of cooling.

- The average cooling water temperature generated using evaporative cooling process was found to be about $17.69 \%$ lower than the ambient conditions. 


\section{ACKNOWLEDGEMENTS}

The authors thankfully acknowledge the ASHRAE Falcon Chapter for funding the project under "Chapter Opportunity Fund". The authors also thank the School of Engineering and IT, MAHE Dubai Campus for providing the facilities to carry out the experimental study.

\section{REFERENCES}

[1] Aste N, Del Pero C, Adhikari RS, Marenzi G. Effectiveness and weaknesses of supporting policies for solar thermal systemsA case-study. Sustainable cities and society. 2015;14:146-53.

[2] Sellami MH, Belkis T, Aliouar ML, Meddour SD, Bouguettaia H, Loudiyi K. Improvement of solar still performance by covering absorber with blackened layers of sponge. Groundwater for Sustainable Development. 2017;5:11-117.

[3] Panchal H, Mohan I. Various methods applied to solar still for enhancement of distillate output. Desalination. 2017;415:76-89.

[4] Jani HK, Modi KV. Experimental performance evaluation of single basin dual slope solar still with circular and square crosssectional hollow fins. Solar Energy. 2019;179:186-94.

[5] Maia CB, Silva FV, Oliveira VL, Kazmerski LL. An overview of the use of solar chimneys for desalination. Solar Energy. 2019;183:83-95.

[6] Jani HK, Modi KV. A review on numerous means of enhancing heat transfer rate in solar-thermal based desalination devices. Renewable and Sustainable Energy Reviews. 2018;93:302-17.

[7] Nazari S, Safarzadeh H, Bahiraei M. Experimental and analytical investigations of productivity, energy and exergy efficiency of a single slope solar still enhanced with thermoelectric channel and nanofluid. Renewable energy. 2019;135:729-44.

[8] Abid M, Yousef BA, Assad ME, Hepbasli A, Saeed K. An experimental study of solar thermal system with storage for domestic applications. Journal of Mechanical Engineering and Sciences. 2018;12(4):4098-116.

[9] Sharshir SW, Peng G, Yang N, Eltawil MA, Ali MK, Kabeel AE. A hybrid desalination system using humidificationdehumidification and solar stills integrated with evacuated solar water heater. Energy conversion and management. 2016;124:287-96.

[10] Abdallah S, Badran O, Abu-Khader MM. Performance evaluation of a modified design of a single slope solar still. Desalination. 2008;219:222-30.

[11] Al-Hayek I, Badran O. The effect of using different designs of solar stills on water distillation. Desalination. 2004;169:121-7.

[12] El-Samadony YAF, Abdullah AS, Omara ZM. Experimental study of stepped solar still integrated with reflectors and external condenser. Experimental heat transfer. 2015;28:392-4.

[13] Mu L, Xu X, Williams T, Debroux C, Gomez RC, Park YH, Wang H, Kota K, Xu P, Kuravi S. Enhancing the performance of a single-basin single-slope solar still by using Fresnel lens: Experimental study. Journal of Cleaner Production. 2019:118094.

[14] Yousef MS, Hassan H. An experimental work on the performance of single slope solar still incorporated with latent heat storage system in hot climate conditions. Journal of cleaner production. 2019;209:1396-410.

[15] Abu-Arabi M, Al-harahsheh M, Mousa H, Alzghoul Z. Theoretical investigation of solar desalination with solar still having phase change material and connected to a solar collector. Desalination. 2018;448:60-8.

[16] Winston DP, Pounraj P, Manokar AM, Sathyamurthy R, Kabeel AE. Experimental investigation on hybrid PV/T active solar still with effective heating and cover cooling method. Desalination. 2018;435:140-51.

[17] Omara ZM, Abdullah AS, Kabeel AE, Essa FA. The cooling techniques of the solar stills' glass covers-A review. Renewable and Sustainable Energy Reviews 2017;78:176-93.

[18] Abu-Hijleh BAK. Enhanced solar still performance using water film cooling of the glass cover. Desalination 1996;107:235-44.

[19] Somwanshi Aneesh, Tiwari Anil Kumar. Performance enhancement of a single basin solar still with flow of water from an air cooler on the cover. Desalination 2014;352:92-102.

[20] Tarawneh MSK. Effect of water depth on the performance evaluation of solar still. Jordon Journal of Mechanical and Industrial Engineering. 2007;1:23-9.

[21] Manokar AM, Winston DP, Kabeel AE, Sathyamurthy R. Sustainable fresh water and power production by integrating PV panel in inclined solar still. Journal of cleaner production. 2018;172:2711-9.

[22] Rajamanickam MR, Ragupathy A. Influence of water depth on internal heat and mass transfer in a double slope solar still. Energy procedia. 2012;14:1701-8.

[23] SOLPOS. Retrieved from https://midcdmz.nrel.gov/solpos/solpos.html; 7 September, 2019. 